\title{
COMMENTS
}

\section{Patronage and the First Amendment: A Structural Approach}

\author{
Ashutosh Bhagwat $\dagger$
}

In Elrod v Burns ${ }^{1}$ and Branti v Finkel, ${ }^{2}$ the Supreme Court held that discharging a public employee because of her political affiliation violates the employee's First Amendment rights to freedom of belief and association. The only exception to this rule is if "party affiliation is an appropriate requirement for the effective performance of the public office involved." Both Elrod and Branti involved challenges to long-standing systems of political patronage, under which elected officials customarily fired non-civil service public employees ${ }^{4}$ appointed by the previous administration and replaced them with members of the elected officials' own political party.

The issue of whether the Elrod rule prohibits patronage employment practices short of discharge has since arisen in lower courts. These practices include demotion, unrequested transfer, reduction of job responsibilities, and hiring itself. Courts almost universally agree that Elrod does prohibit some patronage practices short of discharge, but there is fundamental disagreement among the circuits on the appropriate standard for determining exactly which practices are banned. Generally, two positions can be distinguished: a "strict" standard prohibiting all unfavorable or discipli-

† B.A. 1986, Yale University; J.D. Candidate 1990, The University of Chicago.

427 US 347 (1976).

2445 US 507 (1980).

3 Id at 518.

- Many if not most public employees are "merit" employees, protected from arbitrary discharge by civil service legislation. Approximately half of the employees of the Cook County, Illinois Sheriff's Office, for example, are merit employees. See Elrod, 427 US at 377 (Powell dissenting). 
nary actions based on political affiliation," and a "permissive" standard prohibiting only those actions which are the substantial equivalent of dismissal. ${ }^{\circ}$ Courts' choice between the two approaches has depended on their views of the value of patronage, the importance of the individual right at stake, and the proper role of the judiciary in this intensely political area.

This Comment documents the confusion in the circuits currently surrounding patronage employment practices, and ultimately proposes a much different constitutional standard. Section I examines the current state of the law in this area, discussing both the Supreme Court's decisions and the varying interpretations developed by the circuits. Section II compares and critiques the two basic approaches to the patronage issue in order to determine whether they properly interpret and apply Elrod, whether they are internally consistent and convincing, and whether they provide workable rules of decision. Finally, section III concludes that both prevailing approaches to the patronage problem are flawed: they rely excessively on a rights approach to the First Amendment. This Comment proposes that courts adopt an alternative, structural approach to First Amendment patronage cases. Maintaining the democratic structure of the American polity was one of the Founders' central purposes in drafting the First Amendment, and a judicial role which guards the political process from dominance by an entrenched political party is especially suited to the patronage context; it promises to avoid the flaws and ambiguities of the current individual rights approaches, and to provide a far more principled basis for decision making.

\section{The Current State of the Law}

\section{A. The Supreme Court Cases}

The Supreme Court first treated the issue of patronage firing in Elrod v Burns. In 1970 Richard Elrod, a Democrat, was elected Sheriff of Cook County, Illinois. In keeping with Cook County tradition, he immediately discharged a large number of non-civil-service employees from the Sheriff's Office because they were not Dem-

- See Bennis v Gable, 823 F2d 723 (3d Cir 1987); Agosto De Feliciano v Aponte Roque, 1987 US App LEXIS 10833 (1st Cir), withdrawn and reh'g en banc granted October 5, 1988; Lieberman v Reisman, 857 F2d 896 (2d Cir 1988). See text at notes 35-44 for a discussion of these cases.

- See Delong v United States, 621 F2d 618 (4th Cir 1980); Rutan v Republican Party, 868 F2d 943 (7th Cir 1989), cert granted, No 88-1872, 1989 US LEXIS 3725 (October 2, 1989). See text at notes $22-34$ for a discussion of these cases. 
ocrats and had failed to obtain the sponsorship of a Democratic Party leader. Most of these employees had been appointed by Elrod's predecessor, a Republican, based on their political affiliation. The discharged employees brought a class action challenging their dismissal, and the U.S. Supreme Court held that Elrod's actions violated the plaintiffs' First Amendment rights to freedom of belief and association.

Justice Brennan wrote a broad-ranging plurality opinion, examining the history of patronage and its virtues and vices. ${ }^{7}$ Brennan pointed out that "political belief and association constitute the core of those activities protected by the First Amendment,"8 and that the Court has often invalidated limitations on First Amendment rights as a condition for the grant of a public benefit such as employment. ${ }^{9}$ Since patronage involves content-based limitations on First Amendment rights, Justice Brennan applied strict scrutiny to the dismissals and concluded that the government had failed to establish a sufficiently compelling interest to justify this infringement of First Amendment rights. ${ }^{10}$

Justice Brennan thus found two constitutional violations stemming from patronage: first, using governmental power to favor a particular viewpoint in the political arena and, second, placing an unconstitutional limit on an individual's First Amendment right to freedom of association in the granting of a public benefit. The first is a structural objection, concerned with protecting the "free functioning of the electoral process" from the danger that patronage will tip "the electoral process in favor of the incumbent party."11 The second involves more traditional First Amendment analysis, concentrating on the infringement of individual rights by government action. Under this view, patronage is unconstitutional when it forces public employees to compromise their right to affiliate with the political party of their choice. ${ }^{12}$ A majority of the Court

7 Brennan recognized, however, that the specific question before the Court "concerned only [] the constitutionality of dismissing public employees for partisan reasons." 427 US at 353 (emphasis added).

Id at 356 .

- Id at 358-59, citing Perry v Sindermann, 408 US 593, 597 (1972). Brennan also cited several cases holding that the government may not deny public employment solely because of membership in a "subversive" organization such as the Communist Party. Keyishian v Board of Regents, 385 US 589 (1967); Cafeteria Workers v McElroy, 367 US 886 (1961).

${ }^{10}$ Elrod, 427 US at 373 ("any contribution of patronage dismissals to the democratic process does not suffice to override their severe encroachment on First Amendment freedoms").

11 Id at 356.

12 Id at 359. 
agreed only with this second prong of the Brennan opinion, limiting the Court's holding to dismissal of a "nonpolicymaking, nonconfidential government employee."13

Justice Powell wrote a lengthy dissent, which began by pointing out that the plaintiffs had originally received their jobs under a patronage system, and may thereby have waived their constitutional rights. ${ }^{14} \mathrm{He}$ then argued that even if a right had been infringed, the contributions of patronage to our two-party democratic system provide the compelling governmental interest necessary to justify the infringement. ${ }^{15}$ Powell reasoned that by increasing political participation and facilitating more efficient and responsive local government, patronage has historically been a positive force in the evolution of American democracy. ${ }^{16}$

The second and final Supreme Court case addressing patronage is Branti $v$ Finkel. In Branti, two assistant public defenders challenged their dismissal by the newly appointed Democratic public defender of Rockland County, New York. The public defender did not attempt to coerce these plaintiffs into changing their political affiliation; he simply fired them, as had been done in Elrod. In this case, moreover, these plaintiffs were arguably confidential or policymaking employees. ${ }^{17}$ The Court, by Justice Stevens, reaffirmed its holding in Elrod that the First Amendment protects public employees from patronage discharges, and found the lack of specific coercion to change parties irrelevant to the Elrod rule. ${ }^{18}$ The Court modified Elrod slightly, limiting the "confidential or policymaking employee" exception to situations where "the hiring authority can demonstrate that party affiliation is an appropriate requirement for the effective performance of the public office involved."19 Once again, the holding was explicitly limited

${ }^{13}$ Id at 375 (Stewart concurring). Justice Stewart's brief concurrence (joined by Justice Blackmun) relied only on the second prong of the Brennan opinion and created an exception for policymaking, confidential employees. Since Justices White and Marshall joined the Brennan opinion, only Justice Stewart's basis for decision commanded the support of five justices. (Justice Stevens did not participate.)

14 Id at 380 (Powell dissenting, joined by Burger and Rehnquist). For a discussion of waiver by government employees of their right to freedom of speech, see Cass R. Sunstein, Government Control of Information, $74 \mathrm{Cal} \mathrm{L}$ Rev 889, 914 (1986).

15 Elrod, 427 US at 387 (Powell dissenting).

${ }^{16}$ Id at 384-87 (Powell dissenting).

17 The plaintiffs were lawyers who worked in a close and confidential relationship with others in the office. See Branti, 445 US at 521 (Stewart dissenting), comparing a public defender's office to a private law firm and emphasizing the degree of confidentiality and trust inherent in such a relationship.

18 Id at 517.

${ }^{20} \mathrm{Id}$ at 518. 
to patronage dismissals. ${ }^{20}$

These two cases constitute the sum of Supreme Court jurisprudence in the patronage area. ${ }^{21}$ The decisions prohibit the discharge of public employees on the basis of their political affiliation, unless the hiring authority can demonstrate that political affiliation is an appropriate requirement for the effective performance of the job. The Court has never specifically addressed the constitutionality of patronage practices short of dismissal, and in fact has explicitly left the question open. ${ }^{22}$ The law governing these practices has developed instead in the U.S. Courts of Appeals.

\section{B. The Circuit Courts and Patronage Practices Short of Dismissal}

1. The Delong Test.

Shortly after Branti, the Fourth Circuit considered the applicability of the Supreme Court patronage decisions to employment practices other than dismissal. In Delong $v$ United States, ${ }^{23}$ a federal officer, the Maine State Director of the Farmers Home Administration, challenged his reclassification and transfer to Washington, D.C. following Jimmy Carter's 1976 election. Delong's alleged injury involved no loss of pay or grade, but rather relocation and a substantial reduction in responsibility. ${ }^{24}$ The district court dismissed Delong's claim because his was a policy making position.

On appeal, the circuit court remanded the case for reconsideration in light of Branti, but also discussed whether transfer and reassignment may ever prove to be unconstitutional burdens. The court first stated that "the Elrod-Branti principle must be construed to provide protection against a wider range of patronage burdens than threatened or actual dismissals." ${ }^{25}$ All circuits to

${ }^{20}$ Id at $512 \mathrm{n}$ 6. Justice Stewart dissented in this case, and Justice Powell (again joined by Justice Rehnquist) also dissented, essentially repeating his arguments in Elrod.

21 At the beginning of the 1989 Term, the Supreme Court granted certiorari to a case squarely presenting the issue of employment practices short of discharge. Rutan $v$ Republican Party, 868 F2d 943 (7th Cir 1989), cert granted, No 88-1872, 1989 US LEXIS 3725 (October 2, 1989). The Seventh Circuit's treatment of the case is discussed at notes 27-35.

${ }^{22}$ Branti, 445 US at 513 n 7, citing Elrod, 427 US at 353 (Stewart concurring). But response to the issue is to be expected in the Supreme Court's decision of Rutan, 1989 US LEXIS 3725.

${ }^{23} 621$ F2d 618 (4th Cir 1980).

24 Delong alleged that in Maine he had "final authority over about $\$ 130$ million annually in loans, and administrative leadership ...," but in Washington was given low-level, uninteresting, and unpleasant duties. Id at 621.

${ }^{25}$ Id at 623. 
consider the issue since have agreed, giving public employees at least as much, and usually more, protection than the Delong court did.

The Delong court went on to limit this constitutional protection to those patronage practices "that can be determined to be the substantial equivalent of dismissal," or which "impose such a Hobson's choice between resignation and surrender of protected rights as to be tantamount to outright dismissal."26 The test is essentially a subjective one, turning on the reasonable expectations and reliance of the employee, so that the vulnerability of a particular employee to adverse action could determine the constitutionality of the government behavior.

The Delong test is the narrowest interpretation of Elrod in the area of non-dismissal patronage actions, and until recently no other circuit had followed it. However, in February of 1989 the Seventh Circuit, sitting en banc, adopted a version of the test in Rutan $v$ Republican Party. ${ }^{27}$ In Rutan, the plaintiffs brought a class action suit against the Governor of Illinois and the Republican Party, challenging the use of political considerations in decisions involving hiring, re-hiring after a layoff, transfers, and promotions of employees. ${ }^{28}$ Plaintiffs alleged that they were denied a wide variety of benefits when employed by or seeking employment with the State of Illinois.

The majority adopted Delong's "substantial equivalent of dismissal" standard and remanded the case for reconsideration. ${ }^{29}$ The court made clear, however, that it would not scrutinize matters such as pure hiring decisions under the new standard. ${ }^{30}$ It reasoned that the limited nature of the Supreme Court's Elrod and Branti decisions did not warrant extension beyond patronage dismissals. ${ }^{31}$ Judge Manion also conducted a generalized cost/benefit analysis, and relied on Justice Powell's dissent in Elrod to conclude that the

${ }^{28}$ Id at 624 .

${ }^{27} 868$ F2d 943 (7th Cir 1989), cert granted, 1989 US LEXIS 3725 (October 2, 1989). The majority opinion is essentially identical to the original panel opinion, reported at 848 F2d 1396 (7th Cir 1988). Both opinions are authored by Judge Manion.

${ }^{28}$ Rutan, 868 F2d at 944.

${ }_{28}$ The court relied on Parrett $v$ City of Connersville, 737 F2d 690 (7th Cir 1984), a case discussing "constructive dismissal" in a very different context, to establish the contours of this standard. 868 F2d at 950 . The only perceptible difference between the Rutan and Delong tests concerns the objectivity of the inquiry; in Rutan, the crucial question was "whether a partisan decision imposed such a burden upon a particular employee that it would have led a reasonable employee to quit." Id at 956 (emphasis added).

${ }^{30}$ Rutan, 868 F2d at 952.

${ }^{31}$ Id at 951-52. 
substantial governmental interest in patronage argues strongly against abolition of all patronage practices. ${ }^{32}$

In his dissent, Judge Ripple sharply questioned the majority's heavy reliance on Powell's dissent in Elrod, and particularly Powell's discussion of the strong governmental interest in maintaining patronage. ${ }^{33}$ The Elrod plurality had in fact explicitly rejected the government's claim that patronage was valuable to the democratic process $^{34}$ and so, the dissent charged, the Rutan majority was "rely[ing] on a point of view that higher authority ha[d] rejected."

\section{The Bennis Test.}

The leading case advocating a stricter reading of Elrod and Branti is Bennis $v$ Gable. ${ }^{36}$ Police officers in Allentown, Pennsylvania who had supported the incumbent mayor's opponents in the two previous elections claimed that they had been demoted to make room for the mayor's political supporters. The Third Circuit held that Elrod applied to actions short of dismissal because "the constitutional violation is not in the harshness of the sanction applied, but in the imposition of any disciplinary action for the exercise of" First Amendment rights. ${ }^{37}$ The court refused to consider whether firing should be distinguished from other employment actions, saying that Elrod clearly covered non-dismissal disciplinary actions. ${ }^{38}$ Since the court did not try to balance the costs of rights infringement against the benefits of patronage, it avoided the subjective assessments of patronage practices conducted by the Elrod, Branti, Delong, and Rutan courts. At the same time, however, the Bennis court failed to justify this apparent departure from Supreme Court precedent.

The Second Circuit recently adopted the Bennis rule in Lieberman $v$ Reisman. ${ }^{39}$ Lieberman is a bit unusual because the challenged governmental actions were taken in retaliation both for the plaintiff's decision to run for political office and for her political

${ }^{32}$ Id at 953-54.

${ }^{33}$ Judges Cudahy and Ripple filed dissenting opinions. Id at 958-59. Both relied on Judge Ripple's vigorous dissent from the original Rutan panel opinion, 848 F2d at 1412, arguing for adoption of one of the stricter standards in the patronage area.

${ }^{34} 427$ US at 369.

35848 F2d at 1415 (Ripple dissenting).

36823 F2d 723 (3d Cir 1987).

${ }^{37}$ Id at 731 (emphasis added).

38 Id.

39 857 F2d 896 (2d Cir 1988). 
affiliation. The court proceeded as if a single standard applied regardless of the employer's motive, and summarily adopted the Bennis rule that " $[w]$ henever ... unfavorable action is taken against a person on account of that person's political activities or affiliation, it raises First Amendment concerns." 40 The court thus reinstated the plaintiff's First Amendment claim, which had been dismissed by the district court, and remanded for further proceedings. ${ }^{41}$

The Bennis and Lieberman opinions-and to an even greater degree, some commentators- ${ }^{42}$ commit a similar error in their readings of the Supreme Court precedents: they rely heavily on the very broad language of Justice Brennan's opinion in Elrod, ignoring this fact that the opinion failed to garner a majority. It is true that Brennan's opinion in Elrod contains generalized attacks on every type of patronage practice, ${ }^{43}$ but Justices Stewart and Blackmun, who completed the majority necessary for the decision, specifically refused to join in that broad discussion of patronage. ${ }^{44}$ There is thus no indication that the Court as a whole would support a broad extension of Elrod. ${ }^{45}$

\section{Patronage in Hiring and Contracting}

Before moving to an evaluation of the circuit courts' treatment of practices short of discharge, it is worth considering cases in related areas such as patronage hiring and contracting. These cases apply the same body of doctrine in only slightly different contexts and, under the structural approach proposed in section III of this Comment, would be analyzed in the same way as discharge cases.

In Avery $v$ Jennings, ${ }^{46}$ the Sixth Circuit heard a challenge to an informal patronage hiring system, in which political officials depended on a network of friends and associates to make hiring decisions. The system was not based explicitly on political affiliation,

40 Id at 900 .

41 See also Agosto de Feliciano v Aponte Roque, 1987 US App LEXIS 10833 (1st Cir), withdrawn and reh'g granted en banc (Oct 5,1988 ), adopting a rule very similar to the Bennis approach.

${ }^{42}$ See Comment, First Amendment Limitations on Patronage Employment Practices, 49 U Chi L Rev 181, 185.86 (1982); Comment, Republicans Only Need Apply: Patronage Hiring and the First Amendment in Avery v. Jennings, 71 Minn L Rev 1374, 1390 (1987).

${ }^{43}$ See 427 US at 356, 369-70.

4 Id at 274 (Stewart concurring).

${ }^{45}$ See Rutan, 868 F2d at $948-49$ (suggesting that the Supreme Court's opinions reveal an intention to limit Elrod decision to its facts).

48786 F2d 233 (6th Cir 1986). See Comment, 71 Minn L Rev 1374 (cited in note 42) for an exhaustive discussion of the case. 
but had the effect of favoring the incumbent's political party. ${ }^{47}$ The court held that this system did not violate the Constitution, but also stated in dictum that "the [F]irst [A]mendment prohibits official hiring policies based solely on political affiliation."48

Before Rutan, the Seventh Circuit appeared more receptive than the Sixth Circuit to First Amendment claims challenging failures to promote politically disfavored employees. In Hermes $v$ Hein, ${ }^{49}$ police officers claimed that they had been denied promotions because they were not politically affiliated with the incumbent government of Wheeling, Illinois. The court affirmed summary judgment for the defendants on the ground that the plaintiffs failed to prove that political affiliation underlay the denials of promotion. The court seemed to imply, however, that if the plaintiffs had been able to prove causation, they would have prevailed, and thus that Elrod may apply to employment practices such as denials of promotions. ${ }^{50}$

Finally, a number of cases have arisen concerning patronage practices in government contracting, with private businesses claiming that their bids on public contracts had been rejected solely because they had not supported the incumbent political powers. The leading cases challenging the government's use of public contracts to reward loyal supporters are Sweeney $v$ Bond, ${ }^{, 2}$ Fox \& Co. $v$ Schoemehl, ${ }^{52}$ LaFalce $v$ Houston, ${ }^{53}$ and Horn $v$ Kean. ${ }^{54}$ All four of the decisions refused to extend Elrod's protection to private contractors, reasoning that patronage contracting practices impose much smaller burdens on freedom of expression than do patronage employment practices. ${ }^{55}$

47 Avery, 786 F2d at 234-35.

48 Id at 234 (emphasis added). See also Messer v Curci, 806 F2d 667 (6th Cir 1986), rev'd en banc, 881 F2d 219 (1989) (involving claims by seasonal maintenance workers that they were not hired because they failed to work in a gubernatorial campaign). See Comment, 71 Minn L Rev at $1378 \mathrm{n} 23$ (cited in note 42) for a discussion of recent cases. See also Comment, $49 \mathrm{U}$ Chi L Rev at 200-02 (cited in note 42), arguing that Elrod should be applied to patronage hiring.

19742 F2d 350, 353-54 (7th Cir 1984).

so Id at 353 and $n$ 3. Recall, however, that the Seventh Circuit took a more restrictive approach to failures to promote in Rutan, 868 F2d at 954-55.

${ }^{81} 669$ F2d 542 (8th Cir 1982).

${ }^{32} 671$ F2d 303 (8th Cir 1982).

s3 712 F2d 292 (7th Cir 1983).

st 796 F2d 668 (3d Cir 1986) (en banc).

ss LaFalce contains the most sophisticated analysis of the patronage hiring issue. 712 F2d at 294. Interestingly, the opinion by Judge Posner suggests that although Elrod covers only the discharge of a public employee, "[r] etribution short of discharge is actionable on the same principle." Id at 293. This statement directly contradicts the Seventh Circuit's 


\section{Assessing the Delong and Bennis Tests}

\section{A. Ambiguity and Inefficiency}

The case law addressing patronage employment and the First Amendment has unfortunately produced vague, ambiguous standards. Ambiguity poses several problems in the patronage context. First, as is true in many other areas of law, lack of clarity is inefficient: it increases uncertainty and the volume of litigation. Beyond inefficiency, however, lies a more troubling intrusion of the judiciary on the independent operation of local governments and the executive branch. This section explores these concerns in turn.

Basic efficiency principles argue for the adoption of an unambiguous standard in patronage employment cases. A clear rule which all parties can comprehend reduces uncertainty and diminishes the amount of litigation. Employees will know when their rights have been violated, and will sue only then. Employers will in turn be aware when they have acted impermissibly, and so will tend to settle quickly. Furthermore, bright-line rules reduce the overall number of violations, since employers will accurately perceive the risk of liability associated with particular conduct. The lowering of administrative costs is a fundamental social gain from which all parties benefit. As the Rutan court recognized, excessive litigation of employment issues is extremely harmful to society because it reduces the efficiency of government and provides no countervailing advantages. ${ }^{56}$

The Delong-Rutan rule, however, is particularly vulnerable to this criticism. The Delong opinion creates an especially ambiguous standard, because it suggests that "both objective and subjective factors pertaining to the office holder's expectations and reliance" are relevant to the court's decision. ${ }^{57}$ The employer cannot be aware of the employee's subjective expectations, while the employee cannot know how a court will assess those subjective factors. The inherent uncertainty of the Delong standard may well explain why it has been accepted by so few courts.

The Rutan version of the Delong rule makes some effort to correct this flaw by adopting a more objective standard. Judge Manion emphasized that the crucial consideration is "whether a partisan decision imposed such a burden upon a particular employee

holding in Rutan. For further discussion and criticism of the patronage contracting cases, see Comment, Political Patronage in Public Contracting, 51 U Chi L Rev 518 (1984).

so Rutan, 868 F2d at 954.

${ }^{37}$ Delong, 621 F2d at 624 . 
that it would have led a reasonable employee to quit."'58 Unfortunately, the "reasonable employee" concept is far from clear, since juries and judges may disagree on what is reasonable. Furthermore, Judge Manion also suggested, rather confusingly, that courts should consider "some special circumstances" in the case of individual employees. ${ }^{59}$ Thus, it is unclear whether the mixture of objective and subjective factors advanced by the Rutan court is any easier to apply than the original Delong standard, since both approaches require an ad hoc assessment of the burden imposed on the employee by the challenged action.

The Bennis-Lieberman approach seems on the surface to provide somewhat more certainty than Delong and Rutan. However, the Bennis and Lieberman courts wrote, too broadly, that the First Amendment bans "the imposition of any disciplinary action" for the exercise of First Amendment rights. ${ }^{60}$ Some implied limit must be read into the Bennis approach simply to limit the volume of litigation, ${ }^{\text {ex }}$ but the Bennis court provides no indication of the appropriate line between actionable and non-actionable employer behavior. The Bennis decision is thus ambiguous, and implicates all of the disadvantages and costs stemming from a vague rule.

The problems caused by ambiguous rules are, of course, not unique to this area of the law. They follow directly from the efforts of courts to develop flexible rules responsive to the merits of claims by individual plaintiffs. ${ }^{62}$ For example, the difficulties of employing a "reasonable man" standard have long been recognized and tolerated in tort litigation. And many areas of constitutional law involve vague, subjective standards which are as difficult to enforce as the standards discussed above. What makes ambiguity a particularly troublesome problem in the patronage area is the extremely intrusive effects of patronage litigation on the workings of state and local governments.

Lawsuits challenging patronage on constitutional grounds re-

${ }^{\text {s8 }}$ Rutan, $868 \mathrm{~F} 2 \mathrm{~d}$ at 956 (emphasis added). Note that the actual employee need not quit, so long as a reasonable employee would have.

s8 Id at 955 .

${ }^{80} 823 \mathrm{~F} 2 \mathrm{~d}$ at 731 (emphasis added); $857 \mathrm{~F} 2 \mathrm{~d}$ at 900 (emphasis added).

-1 Agosto, 1987 US App LEXIS 19833 at 9, citing Bart $v$ Telford, 677 F2d 622, 625 (7th Cir 1982). The standard adopted by the Agosto court is itself ambiguous, prohibiting a "substantial and permanent lessening of both the internal satisfactions that have accompanied a job and the external prestige that has accompanied the position." 1987 US App LEXIS 19833 at 9.

${ }_{62}$ As discussed in section III, these problems can be limited if courts pay less attention to the merits of individual concerns, and formulate their rules more on the basis of the social and structural costs of the regulated behavior. 
quire the federal judiciary to interfere with the employment practices of either state and local governments, or, in the case of challenges to federal patronage, a co-equal branch of the national government. This is a uniquely inappropriate area for courts to involve themselves. The capacity to hire and fire employees free of judicial intervention is essential to the independent operation of local governments and the executive branch. ${ }^{63}$ Although the federal judiciary clearly has the power to supervise the activities of state governments when enforcing constitutional norms, and though employment practices themselves are examined under the Equal Protection Clause, the power nonetheless is one that the courts should exercise with prudence. ${ }^{64}$

An ambiguous standard governing patronage employment deeply undermines this prudential consideration because it introduces great uncertainty and the threat of litigation into every employment decision by a local government. Since every adverse action against an employee may provide yet another basis for a lawsuit under this regime, employers are tightly constrained in their actions to make certain that they do not approach the constitutional limits of their power. Judicial involvement with the structure of governmental employment practices is therefore profoundly antimajoritarian, enabling an appointed elite, the judiciary, to influence the elected representatives of the voting public. ${ }^{\circ 6}$ Thus, fundamental principles of the Constitution argue for a clear, easily interpreted standard.

B. The Use of Freedom of Speech Doctrine in Freedom of Association Cases: The Failure of Balancing

The presence of vague and ambiguous rules governing patronage practices is not, however, solely the fault of the circuit courts of appeals. To a significant degree, the problem follows in-

${ }^{63}$ For a discussion of these issues, see National League of Cities $v$ Usery, 426 US 833 (1976), overruled by Garcia v San Antonio Metropolitan Transit Authority, 469 US 528 (1985). While Garcia eliminated direct judicial enforcement of federalism standards protecting local governments from federal intervention, it did not question the conclusion of $\mathrm{Na}$ tional League of Cities that control of one's employment practices is a crucial aspect of sovereignty.

64 427 US at 375-76 (Burger dissenting). Chief Justice Burger argues in his Elrod dissent that courts should show extreme deference to the decisions of state legislatures on how they wish to structure their public employment systems.

${ }^{65}$ See Note, Politics and the Non-Civil Service Public Employee: A Categorical Approach to First Amendment Protection, 85 Colum L Rev 558, 574 (1985) (discussing the antimajoritarian problem and the advantages of clear, categorical rules over ad hoc balancing tests). 
evitably from the approach of the Supreme Court in Elrod and Branti. In Elrod, the Court applied doctrine developed in cases involving the freedom of speech rights of public employees to a freedom of association case. The Court relied on Pickering $v$ Board of Education, ${ }^{66}$ in which a public school teacher's discharge for exercising his First Amendment rights had been invalidated. The Pickering Court reasoned that even though the government can deny public benefits such as employment altogether, it cannot subject them to unconstitutional conditions. ${ }^{67}$ The Court conceded, however, that the First Amendment rights of public employees are not absolute, and that the harm to the employee must be weighed against the important governmental interests in restricting the employee's rights. This is the origin of the famous Pickering balancing test, applied in Elrod. ${ }^{68}$ The circuit courts that have applied and extended Elrod have generally followed the lead of the Supreme Court and attempted Pickering-type balancing.

Unfortunately, there is something fundamentally incorrect in applying Pickering balancing to patronage cases. As the following section will show, the individual rights at stake in patronage cases are extremely different from the rights involved in expression cases. Furthermore, the countervailing governmental interests are also of an entirely different nature. Thus, a blind application of Pickering to patronage cases may produce incoherent results.

In the area of individual rights, the differences between freedom of expression and freedom of association are immediate and obvious. First, speech is an enumerated right, explicitly protected by the First Amendment, while political association is a derivative right of recent origin, read into the Constitution by the Court. ${ }^{69}$ Since the recognition of constitutional rights in the patronage context is especially recent, it may well be that under a literalist approach to constitutional interpretation, freedom of association cannot command the same strict scrutiny as freedom of speech. ${ }^{70}$ Furthermore, association is clearly not speech, even if protecting it

66 391 US 563 (1968). For discussions of the roots of the Elrod decision, see Rutan, 868 F2d at 947-48; Bennis, 823 F2d at 731; Comment, $49 \mathrm{U}$ Chi L Rev at 184-85 (cited in note 42).

67391 US at 568.

68 Justices Brennan and Stewart both relied heavily on Perry $v$ Sindermann, 408 US 593 (1972), where the Court applied Pickering balancing to a claim by an untenured professor at a state college that he had been denied reemployment because he exercised his First Amendment speech rights. Elrod, 427 US at 358-59, 375.

69 See Elrod, 427 US at 357, citing Buckley v Valeo, 424 US 1, 11 (1976) and preceding cases.

${ }^{70}$ See Agosto, 1987 US App LEXIS 10833 at 9. 
is necessary to protect speech. The Elrod opinions assumed without explanation that speech and association are entitled to the same protection, ${ }^{71}$ a dubious proposition in light of the peculiar nature of the claims raised by plaintiffs in patronage cases.

The second side of the Pickering equation, the governmental interest justifying restrictions on public employees' First Amendment rights, is also of a fundamentally different nature in the patronage cases than in the speech and expression cases. In the speech cases, the government can usually assert a very specific reason for restricting the speech at issue such as national security concerns, ${ }^{72}$ the maintenance of discipline and order in the workplace, ${ }^{73}$ or the suppression of organizations with unlawful purposes. ${ }^{74}$ These represent narrowly focused government interests, which can be weighed manageably against an individual right. Since each case involves a different interest, a balancing test is essential to determine if the governmental restriction is justified.

In the patronage cases, however, the government asserts a completely different type of interest. The major arguments in favor of allowing patronage are broad-based, structural ones which describe the importance of patronage to the political system. For example, governmental employers have claimed that patronage helps "to insure effective government and the efficiency of public employees,"75 that "[p]atronage practices [broaden] the base of political participation," "76 that "[p]atronage appointments help build stable political parties," $" 77$ and that patronage permits voters indirectly to elect a larger number of public officials. ${ }^{78}$ Whatever the accuracy of these assertions, it is notable that all are extremely broad and absolutely uniform; they do not vary from case to case. This brings into question the need for a balancing test of any sort, since at least one side of the equation is constant. An explicit standard assessing only the variable side of the equation would be simpler and more exact.

${ }^{71}$ As discussed in note 68, both Justices Brennan and Stewart relied heavily on Perry $v$ Sindermann. Since Perry involved freedom of expression, it appears that neither justice distinguished between expression and association.

${ }^{72}$ See Snepp v United States, 444 US 507 (1980). See also Sunstein, 74 Cal L Rev at 913 (cited in note 14) for a discussion of the case.

${ }^{73}$ See Pickering, 391 US at 569-71.

74 See Keyishian v Board of Regents, 385 US 589, 605-06 (1967) (membership in the Communist Party).

${ }^{75}$ Elrod, 427 US at 364.

${ }^{78}$ Id at 379 (Powell dissenting).

77 Branti, 445 US at 527 (Powell dissenting).

${ }^{78}$ Id at 533-34 (Powell dissenting). 
The vague, structural, and extremely political nature of the issues involved in patronage cases makes one wonder whether the judiciary should decide patronage issues at all. Judge Posner has stated that the reduction of patronage "raises profound questions of political science that exceed judicial competence to answer." is noteworthy that when judges have evaluated the arguments for and against patronage, they have reached their conclusions summarily and have varied profoundly in their conclusions. In Elrod, for example, Justice Brennan simply dismissed the suggestion that patronage improves governmental efficiency, or that it might play an important role in preserving the two-party system. ${ }^{80} \mathrm{He}$ offered no empirical evidence to support his conclusions. Similarly, Justice Powell's argument in favor of patronage, adopted by Judge Manion in Rutan, lacks any empirical foundation. ${ }^{81}$ In fact, Judge Ripple's dissent in Rutan specifically objected to the majority's use of its "own predilections" in evaluating patronage, and argued for a remand to develop a better factual record concerning the actual advantages and costs of patronage systems. ${ }^{82}$ It is the failure of the Pickering approach in the patronage context that has produced the circuit split between the Delong-Rutan and the Bennis-Lieberman line of cases, described in subsection B of Section I.

A circuit split is not normally sufficient reason to reject the rule itself, but in the patronage area it may well be. This circuit split is unprincipled. Both the Delong and Bennis solutions to the patronage problem suffer from ambiguity and arbitrariness, suggesting that any conclusion the Supreme Court might reach by applying Pickering to resolve the circuit split would be equally ambiguous and arbitrary. Furthermore, the costs of an incorrect decision on the issue, measured in terms of inefficiency and needless federal interference in the operation of local governments, could be immense.

Thus if patronage questions should be resolved by balancing the individual interest against this broadly stated governmental interest, the judiciary should perhaps leave the balancing process to the branch more accustomed to carrying out empirical investigations, the legislature. The propriety of patronage practices is just the sort of hotly debated and amorphous political issue that the judiciary should try to avoid. In addition, since legislatures gener-

79 LaFalce, 712 F2d at 294.

so 427 US at $364,369$.

81 Id at 378-89 (Powell dissenting); Rutan, 868 F2d at 953.

$82848 \mathrm{~F} 2 \mathrm{~d}$ at 1414-15 (Ripple dissenting). 
ally have protected many, if not most, public employees from patronage practices by the passage of civil service laws, ${ }^{83}$ their failure to act may represent a conscious policy decision not to protect the particular employees.

There is, however, an approach to the patronage issue that rehabilitates the role of the judiciary. If the First Amendment is viewed as a structural provision, meant to defend not so much individual rights as a societal interest in free democratic processes, then judicial resolution of the patronage cases is appropriate. Under this view, there are profound reasons for thinking that the political branches are fundamentally incapable of dealing with the concerns raised by patronage. Therefore, the judiciary not only may act, but must act.

\section{The First Amendment: A Structural Approach}

The development of First Amendment jurisprudence has centered around the concept of individual rights. Most scholars and jurists view the Amendment as granting to individuals specific entitlements which protect them from government interference with their freedom of expression. The reasons for this view are historical and probably, at least to a degree, coincidental. Much of modern First Amendment jurisprudence hearkens back to the great dissents of Justice Holmes in Abrams $v$ United States ${ }^{84}$ and Gitlow $v$ New York. ${ }^{85}$ The fact that these cases involved constitutional challenges to criminal convictions for very serious crimes may help to explain much about the development of doctrine in this area, for it is only natural that challenges to criminal convictions focus on individual rights. Whether that approach should have been exported into other areas of First Amendment law, however, is questionable.

Side by side with the individual rights view of the First Amendment, another quite different approach has existed since the time of the Founders. Under this view, the First Amendment's primary concern is not protection of the rights of individual citizens to speak out, but protection of the democratic process from subversion by the powers controlling the government. This struc-

${ }^{83}$ See Frank J. Sorauf, Party Politics in America 88 (Little, Brown, 2d ed 1972) ("Any number of states, counties and cities-the great majority probably-have virtually abolished patronage, moving to merit systems of some sort."). See also David W. Abbott and Edward T. Rogowsky, Political Parties: Leadership, Organization, Linkage 93 (Rand McNally, 1971).

84250 US 616 (1919).

${ }^{85} 268$ US 652 (1925). 
tural approach presumes that if the political process remains untainted, then the sovereign people can be counted on to protect their own freedoms. Under this view, the First Amendment (and the Constitution generally) does not incorporate particular values; it provides a framework for government within which the people may express and enforce their collective values, which presumably will change over time.

Of course, these two approaches to the First Amendment are not mutually exclusive; it may well be that they are complementary, and the appropriateness of each approach will depend on the specific area of law at issue. In any particular area of jurisprudence, however, one must choose between the two approaches for the simple reason that they yield entirely different rules of decision. In the area of freedom of association jurisprudence and political patronage, the structural approach to the First Amendment seems clearly preferable, producing a rule of decision that is both simple and logical when applied to the questions at stake in cases like Delong, Bennis, and Rutan.

\section{A. Exponents of the Structural View}

The drafters of the First Amendment clearly sought to protect the democratic process. They considered freedoms guaranteed in the Amendment, particularly the freedom of the press, essential to the preservation of liberty and democracy. ${ }^{86}$ This is not to say that protecting democracy was the sole purpose of the Amendment, since freedom of conscience was certainly treated as an important natural right in itself. But guarding democracy was one of the Amendment's fundamental objectives. In interpreting the First Amendment, however, courts have traditionally put great weight on the freedom of conscience/personal rights aspects of the Amendment at the expense of its structural objectives.

James Madison, in response to the passage of the Sedition Laws, put forth one of the clearest statements of the importance of First Amendment freedoms to the democratic process. Madison first pointed out that democracy and elections simply could not function without full freedom of speech, since knowledge about the candidates in an election was dependent on "equal freedom ... of

s6 "[F]reedom of the press is one of the great bulwarks of liberty." Virginia Declaration of Rights, Sec 12 (June 12, 1776), quoted in Philip Kurland and Ralph Lerner, eds, 5 The Founders' Constitution at 121 (U of Chicago, 1987). See also David Hume, Of the Liberty of the Press (1742), quoted in Kurland, 5 Founders' Constitution at 117 (discussing the importance of the press in "curb[ing] the ambition of the [monarch]"). 
examining and discussing these merits and demerits of the candidates respectively."87 Madison pointed out that if the government is permitted to abridge First Amendment freedoms, "[w]ill not those in power derive an undue advantage for continuing themselves in it, which, by impairing the right of election, endangers the blessings of the Government founded on it?" 88 This is the essence of the structural view of the First Amendment. The right of petition and assembly, upon which the right to political association is based, also has strong structural components. ${ }^{89}$

John Hart Ely has advanced the best-known and most complete modern exposition of the structural view of the First Amendment.. ${ }^{90}$ Professor Ely believes that the Constitution and Bill of Rights are by their very nature meant to be blueprints for government rather than repositories of specific moral values: "[T]he body of the original Constitution is devoted almost entirely to structure." ${ }^{11} \mathrm{He}$ argues that the specific value choices originally incorporated into the Constitution, such as the right to bear arms or to full freedom of contract, ${ }^{22}$ have essentially been discarded. Instead, the Constitution has become a safeguard of procedural principles, guaranteeing both that a democratic majority will make the important substantive choices and that the controlling majority will not "systematically treat others less well than it treats itself."93

The judiciary plays a peculiar and crucial role in such a constitutional system. As the non-democratic branch of government, it must ensure that the political branches remain democratic. Ely terms this the "representation-reinforcing" view of the judiciary: "It recognizes the unacceptability of the claim that appointed and life-tenured judges are better reflectors of conventional values than elected representatives, devoting itself instead to policing the mechanisms by which the system seeks to ensure that our elected representatives will actually represent."94 The two great dangers

${ }^{87}$ James Madison, Report on the Virginia Resolution, January, 1800 (Writings 6: 385401), quoted in Kurland, 5 Founders' Constitution at 145 (cited in note 86).

${ }^{88}$ Id.

s9 Justice Story, writing about this provision, said it "would seem unnecessary to be expressly provided for in a republican government, since it results from the very nature of its structure and institutions. It is impossible, that it could be practically denied, until the spirit of liberty had wholly disappeared." Joseph Story, 3 Commentaries on the Constitution $\S 1887$, quoted in Kurland, 5 Founder's Constitution at 207 (cited in note 86).

80 John Hart Ely, Democracy and Distrust (Harvard, 1980).

o1 Id at 90 .

${ }^{22} \mathrm{Id}$ at 100.

${ }^{93}$ Id at 100-01.

94 Id at 102 . 
the judiciary must guard against are "insiders" (those who currently hold power) using the system to "chok[e] off the channels of political change," and "representatives beholden to an effective majority . . . systematically disadvantaging some minority. . . ."øs

Perhaps the paradigmatic situation where the courts have acted to protect the political process is in the "right to vote" cases, including malapportionment decisions such as Baker $v$ Carr, ${ }^{96}$ which held that extreme malapportionment can violate the Equal Protection Clause by debasing the right of some citizens to vote, and voter qualification decisions such as Harper $v$ Virginia Board of Elections, ${ }^{97}$ which prohibited the use of poll taxes in state elections.

The First Amendment has a central role to play in protecting the political process. As the discussion above reveals, the Founders were certainly very aware that freedom of expression, the right to engage in free and open discussion of political issues, is an absolute prerequisite to a functioning democracy. Indeed, in some ways the guarantees of the First Amendment form the centerpiece of the Constitution's structural protections, which may explain why it was the First Amendment. Professor Ely's discussion emphasizes freedom of expression as the crucial right protected by the First Amendment. ${ }^{98}$ But freedom of political association, although not explicitly mentioned in the Constitution, is equally if not more essential to the nurture and protection of the democratic process. Interpretation of the Amendment under a structural approach leads quite naturally to the conclusion that the broad rights to assembly and petition necessarily imply a right to political association; otherwise, the former rights would be rendered almost meaningless.

Alexander Meiklejohn, perhaps his generation's foremost advocate of the structural view of the First Amendment, recognized the importance of the right to political association. Professor Meiklejohn pointed out that if the First Amendment is primarily intended to protect the ability of the citizen-body to govern itself without interference from its chosen agents, then the freedom to vote and the freedom to form political associations are as essential a part of the Amendment as freedom of expression. ${ }^{99}$ Writing dur-

${ }^{95}$ Id at 103. Compare this view of the judiciary's role with that put forward in Garcia $v$ San Antonio Metropolitan Transit Authority, 469 US 528 (1985), where the Court decided that in the area of federalism the political process could be trusted to police itself.

os 369 US 186 (1961).

97 383 US 663 (1966).

${ }^{93}$ Ely, Democracy and Distrust at 93-94 (cited in note 90).

9* Alexander Meiklejohn, The First Amendment is an Absolute, $1961 \mathrm{~S}$ Ct Rev 245, 
ing the McCarthy era, Meiklejohn placed heavy emphasis on the absolute nature of First Amendment rights: the Constitution forbids any interference with the rights of a citizen to hold and express his political views or to associate for political purposes, even if those views or organizations are opposed to the Constitution itself. ${ }^{100}$

Scholars have already examined the implications of a structural view of the First Amendment for the free speech rights of public employees. ${ }^{101}$ Because of the dangers to the democratic process posed by patronage, a structural approach is even more appropriate in that context. And while current patronage jurisprudence focuses on individual rights, there is good reason to think that structural considerations have also been an important developmental force, especially in the Supreme Court.

\section{B. Why a Structural Approach to Patronage?}

As the above discussion reveals, the personal rights and the structural views of the First Amendment have existed side by side since the days of the Founders. Madison and the other Framers did not consider these two functions of the Amendment to be incompatible or even mutually contradictory; rather, they saw them as two complementary objectives of the Amendment's press, speech, and assembly provisions. However, when developing a particular area of First Amendment jurisprudence, a choice must be made between the two approaches simply because they yield incompatible results. One set of considerations must control if the rules of decision are to be clear and unambiguous. Any mixing or ad hoc, unprincipled balancing of fundamentally different concerns will lead to ambiguity and inconsistency.

In the patronage context, all of the important considerations argue for a structural approach. The structural approach avoids most of the defects of the personal rights approach, such as ambiguity, unworkability, and judicial incapacity, and it better addresses the concerns underlying the Supreme Court's decisions in the area.

The tremendous growth in public sector employment during the last half century has greatly increased the importance of struc-

256.

${ }^{100}$ Alexander Meiklejohn, Political Freedom 56-57 (Harper \& Brothers, 1960). The references, of course, are to the Communist Party. Professor Meiklejohn's view of the First Amendment is extreme, for he denied any individual rights component to the Amendment.

101 See Sunstein, 74 Cal L Rev 889 (cited in note 14). 
tural as opposed to individual rights factors in the patronage context. In the days of limited public employment, the coercive power the government could wield through the grant or denial of such employment was also very limited. Today the government employs a very large number of voters ${ }^{102}$ whom it is able to coerce through a patronage system. Such coercion could possibly affect election results, something which was very unlikely in the days of a small public sector. Thus, the importance of the systemic effects of patronage has increased tremendously since the time of the Founders, and there is reason to argue that while once constitutional, by its pervasiveness patronage has become unconstitutional.

Individual rights, by contrast, do not loom especially large in this context. As noted above, ${ }^{103}$ the association right has a relatively weak pedigree. Moreover, the claims of many plaintiffs in discharge cases are weakened by a problem of unclean hands-though now suffering from patronage, these plaintiffs were once its beneficiaries, and after gaining employment because of their political beliefs they cannot convincingly claim that losing employment because of those beliefs would threaten their "freedom of conscience."

Resort to a structural approach in patronage cases is supported additionally by the the failure of the Pickering personal rights approach to produce a coherent jurisprudence or clear rules of decision. The structural approach cannot guarantee absolute uniformity in judicial decisions, but it does provide judges with a fairly neutral principle on which to base decisions, and tends to minimize the necessity of judges' incorporating their own values into their decisions. ${ }^{104}$

Adoption of a structural approach in patronage decisions would depart somewhat from Supreme Court precedent, but is not without foundation in the Court's earlier rulings. The Court has in fact mixed the two approaches, giving the appellate courts conflicting signals about the relevant sets of considerations. With the circuit courts' predominantly rights-based approach such a resound-

102 In 1947, government employees constituted $5.69 \%$ of the adult population of the United States (where adults are defined as 20 years of age and over, a fair proxy for the voting population). In 1987, the government employed $9.83 \%$ of the adult population. State and local government employees alone were $3.73 \%$ of the adult population in 1947, while by 1987 they were 8.13\%. Annual Report of the Council of Economic Advisors for 1989 343, 356-57 (GPO, 1989). One suspects that figures before 1947 would show an even more rapid increase in the size of the public sector.

${ }^{103}$ See text at notes 69-71.

${ }^{104}$ Ely, Democracy and Distrust at $101-02$ (cited in note 90). 
ing failure, the time would seem ripe for a clear statement that structural concerns are not only crucial, but should predominate over individual rights in patronage cases.

A closer examination of the Supreme Court's opinions in Elrod and Branti, based ostensibly on Pickering and personal rights, reveals that many of the most crucial factors were structural. Justice Brennan's plurality opinion in Elrod $v$ Burns contains a broad set of arguments for finding patronage practices unconstitutional. He focuses on patronage's infringement of the personal rights to freedom of association and belief, a condition necessary to gaining the concurrence of Justices Stewart and Blackmun. But structural concerns played an important, arguably decisive role in Justice Brennan's debate with Justice Powell. At several points, Justice Brennan remarked that patronage "tips the electoral process in favor of the incumbent party," 105 and that "[p] atronage can result in the entrenchment of one or a few parties to the exclusion of others." ${ }^{108} \mathrm{He}$ states elsewhere that associational and speech rights should be protected because they "are essential to a meaningful system of democratic government."107

Justice Powell countered Brennan's structural attack by emphasizing the benefits of patronage. Powell argued that "traditional patronage practices contribute significantly to the democratic process." 108 He claimed that patronage practices strengthen political parties by increasing popular participation in the electoral process and creating closer ties between party leaders and the general membership. ${ }^{108}$ Furthermore, patronage directly increases democratic control over government by allowing voters to elect officials, who in turn appoint lower officials with the same popularly held views. ${ }^{110}$ Whichever position is correct, it is clear that disagreement about the nature of the democratic process underlay the conflict between the Justices.

Structural concerns have played a less important role in appellate court patronage decisions, which tend to mechanically apply Elrod and its Pickering balancing test. As the debate between Judges Manion and Ripple in Rutan indicates, however, structural concerns have influenced the courts' choices between a strict and

\footnotetext{
105427 US at 356.

100 Id at 369.

${ }^{107}$ Id at 369-70.

${ }^{108}$ Id at 384 (Powell dissenting).

${ }^{108}$ Id at 385 (Powell dissenting); Branti, 445 US at 527-32 (Powell dissenting).

${ }^{110}$ Branti, 445 US at 533-34 (Powell dissenting).
} 
permissive approach to patronage. Judge Manion shows that his views of the political process shaped his choice of rules by quoting wholesale Justice Powell's arguments in Branti. ${ }^{111}$ Judge Ripple's position on the structural issues is more subtle, in that he neither adopted Justice Brennan's view nor rejected Justice Powell's. Instead, Judge Ripple placed the responsibility on the plaintiffs to prove their structural allegations, thus making the outcome turn on empirical evidence rather than judicial intuition or bias. ${ }^{112}$

In sum, there are strong reasons for adopting a primarily structural approach to the patronage cases, and doing so will not depart dramatically from existing precedent. While it is true that the important patronage decisions formally have been based on a personal rights approach to the First Amendment, structural concerns have played an important, if not decisive, role in the actual decision making process. And where the first of two approaches espoused by the Court in a formative decision has failed, increased reliance on the second approach seems warranted. By reexamining the problems raised in Delong, Bennis, and Rutan under a structural approach, one can develop rules of decision that are clearer and less the product of personal predilection or individual judicial philosophies.

\section{Implications for the Patronage Cases: Discerning Rules of Decision}

Once one accepts the validity of a structural approach to the First Amendment in certain circumstances, its applicability to the patronage context is obvious. Political patronage is perhaps the crudest, most blatant manner in which government "insiders" use the powers of the state to entrench themselves by strengthening their political party and tilting the results of elections. Under a structural approach, the judiciary must prevent exactly such behavior. In Elrod and its progeny, the federal judiciary in fact acted to curtail such abuses.

As Justice Powell pointed out in his Elrod and Branti dissents, patronage practices clearly have some benefits. Patronage provides elected officials greater control over unelected bureaucracies, and may increase governmental efficiency. But these advantages are not "structural" in the constitutional sense because they do not answer the fundamental objection that in some instances

11. Rutan, 868 F2d at 953 .

${ }^{112}$ Rutan, 848 F2d at 1415 (Ripple dissenting). 
patronage acts to subvert the democratic system itself. Questions about the ideal role of patronage in public employment can be adequately addressed in the political arena, as long as the political process itself remains fair and democratic. The judiciary need not resolve the difficult policy choices between patronage and meritbased civil service systems; it must only guard the democratic system through which these issues are addressed.

Before attempting to resolve the patronage cases under a structural approach, it may be useful to examine the ways and extent to which different kinds of patronage practices affect the democratic process and election results. It is difficult to ascertain the actual amount of patronage employment still existing in this country. Most of the available scholarship suggests that the number of patronage jobs overall has declined significantly in recent years, but that patronage remains a powerful force in some parts of the country. ${ }^{113}$ St. Louis, Pittsburgh, New York, Pennsylvania, and, of course, Chicago have been identified as locales with strong patronage systems. ${ }^{114}$ Furthermore, incumbent politicians often use their influence in the private sector to obtain both financing and jobs for supporters. The late Mayor Daley of Chicago was particularly well-known for placing thousands of his supporters in the private sector. ${ }^{115}$ Thus, patronage remains an important political institution in some parts of the country.

Determining whether patronage actually affects election results is more difficult. Most scholars agree that in those parts of the country where patronage remains common, it significantly affects election returns. In at least some areas, voters associated with patronage jobs represent a significant portion of the voting population, especially when one considers that the family members of the patronage jobholder will probably vote for the patron. ${ }^{116}$ Furthermore, the party soldiers who receive patronage jobs must use their personal influence and promises of political favors to get the vote 1971).

${ }^{113}$ See, for example, Martin and Susan Tolchin, To the Victor . . . 72 (Random House,

114 Sorauf, Party Politics at 88 (cited in note 83). Sorauf reports that into the 1970s Mayor Daley directly controlled 35,000 jobs in Chicago. See also Tolchin, To the Victor... at 72 (cited in note 113) (stating that up to $46 \%$ of municipal jobs are potentially available for patronage).

115 Richard L. Kolbe, American Political Parties: An Uncertain Future 130 (Harper \& Row, 1985). See also Michael Johnston, Political Corruption and Public Policy in America 66 (Brooks/Cole, 1982).

${ }_{116}$ Kolbe, American Political Parties at 144 (cited in note 115). See also Sorauf, Party Politics at 73 (cited in note 83 ). 
out in their wards. ${ }^{117}$ If the soldiers fail to perform these duties, they lose their patronage rewards. ${ }^{118}$ Thus, it seems clear that despite the general decline in patronage practices in recent years, patronage remains an important force in shaping election outcomes in a significant number of jurisdictions.

When applying structural principles to patronage employment practices, the judiciary should be concerned with the systemic social effects of patronage. The crucial factor in evaluating the constitutionality of any particular practice is the extent to which the practice subverts the democratic process by using governmental powers to favor a partisan interest. Thus, the differences between the individual employees involved in the actions and the effects of the practices on those employees are largely irrelevant, except as evidence of the systemic effects. By focusing on the nature of the disciplinary action, the Delong and Rutan courts ${ }^{119}$ misconstrued the inquiry: the crucial consideration should be what the employer is trying to coerce the employee into doing, for it is those activities that could affect the electoral process. The fundamental principle which should underlie all decisions applying the structural approach to patronage cases is that the First Amendment prohibits public employers from forcing public employees to take actions that will change the results of election campaigns involving either incumbents or their political allies.

It is essential that the power of the state not be used to promote any activities that threaten such consequences. Any disciplinary action, no matter how trivial, which is imposed by a public employer for the failure of an employee to perform activities which might help an incumbent's election chances, must be prohibited as an unconstitutional use of public power. ${ }^{120}$ Any use of public power to create anti-democratic entrenchment should be per se unconstitutional. While this rule makes the actual burden on the disciplined employee irrelevant, it accords with the structural approach to the First Amendment, which focuses on protecting the demo-

117 Kolbe, American Political Parties at 144-45 (cited in note 115). But see Johnston, Political Corruption at 57 (cited in note 115) (case study suggesting that handing out patronage jobs did not increase votes received by the incumbent).

118 Sorauf, Party Politics at 74 (cited in note 83).

119 Only actions which are "the substantial equivalent of dismissal" are prohibited. Delong, $621 \mathrm{~F} 2 \mathrm{~d}$ at $624 ;$ Rutan, $868 \mathrm{~F} 2 \mathrm{~d}$ at 950.

${ }^{120}$ Note that this rule, unlike the Bennis test, will not lead to excessive litigation. See text at notes 60-62. Under this rule, plaintiffs may not bring an action unless their employer has required substantial political service from them. This constraint will limit the number of suits filed (and will permit summary disposition of trivial suits). The Bennis court's approach contains no such constraint. 
cratic process, not individual plaintiffs.

The question of whether a particular use of state power actually skews the political process remains a factual inquiry which the courts cannot avoid. However, the inquiry is more focused and empirical than the one the courts currently undertake as part of a personal rights approach to the patronage cases. Neither the subjective burden on the individual employee nor broad questions about the governmental interests advanced by specific patronage practices need be explored. As long as employment practices which lead to entrenchment are clearly delineated, courts can leave the more difficult factual nuances unresolved. A court need only determine whether the patronage practice being challenged could potentially influence electoral outcomes; as long as the practice could not skew elections, courts can trust the democratic process to monitor the employment practices of elected officials. The following discussion highlights the First Amendment implications of several common patronage practices under a structural approach.

\section{Coerced campaign contributions and actual campaigning.}

A structural approach to the First Amendment prohibits public employers from coercing employees into either making monetary contributions or actually campaigning, since these activities strongly and directly affect election results. Strong empirical evidence $^{121}$ (and experience) indicate that the candidate who spends more money tends to win the election. The argument against coercion of campaigning, as opposed to financial contributions, is more difficult to validate empirically, but intuitively just as strong. There is little doubt that in local elections, where the voter pool is fairly small, an incumbent can skew the election in her favor by forcing public employees to campaign for her under threat of adverse employment action such as demotion or transfer. Since under a structural approach the fundamental danger which the judiciary must guard against is this skewing of election outcomes towards incumbents, the general principles developed above establish that the Constitution prohibits any disciplinary actions imposed for failure to contribute money or to campaign for the incumbent.

121 See Daniel H. Lowenstein, Campaign Spending and Ballot Propositions: Recent Experience, Public Choice Theory and the First Amendment, 29 UCLA L Rev 505 (1982), providing empirical evidence that in the context of California ballot propositions, greatly outspending one's opponents significantly increases one's chance of success. See also David Adamany, Money, Politics, and Democracy: A Review Essay, 71 Am Pol Sci Rev 289, 294-95 (1977), for a summary of various studies on the effects of spending on candidate elections. 
Although it sounds similar, the above rule is not the same as the rule adopted by the Bennis court. The Bennis court purported to prohibit any disciplinary action undertaken even for failure to affiliate, ${ }^{122}$ while this rule applies only to attempts to coerce contributions or active campaigning. The real difference is that the structural rule focuses on the requirements imposed on the employee, not the nature of the disciplinary action.

\section{Coerced political affiliation.}

The structural approach suggests a more permissive attitude towards cases involving only coerced affiliation, rather than coerced financing or campaigning. Although there is certainly a great deal of individual coercion in requiring an employee to change political affiliation, the crucial consideration under a structural approach is not the infringement of individual rights, but rather the potential effect on the democratic process. It seems extremely unlikely that forcing changes in political affiliation significantly affects the results of elections.

Requiring public officials to change political affiliation in order to avoid disciplinary action has no effect on the citizen body at large. ${ }^{123}$ Certainly it does not exert the direct influence on public opinion and voting patterns that coercion of finances or campaign workers does. And though public employees themselves represent a significant pool of voters, ${ }^{124}$ and forcing an employee to change party affiliation may have some effect on the way she votes, the employee retains the essential freedom to vote as she pleases, since her ballot remains secret. ${ }^{\mathbf{1 2 5}}$

On the other hand, requiring an employee to change party affiliation could prevent the employee from participating in the organization and campaign efforts of the rival party. Changing affiliation does not always have this effect, however, and the public employer is of course prohibited from punishing the employee for any actual participation in the rival party's organization. A factual

122823 F2d at 731 .

${ }^{123}$ It should be kept in mind that only disciplinary actions short of dismissal, imposed on current employees, are at issue in the Delong/Bennis circuit split. Dismissals have already been invalidated by Elrod, and patronage hiring presents quite a different problem, for reasons discussed below.

124 See note 102.

${ }^{125}$ Of course, the employee's political affiliation could, in the absence of cross-over voting, determine which primary she could vote in. Whether this is enough skewing to justify finding a constitutional violation is an open question, but it should be noted that, ex ante, this effect does not seem to particularly favor the incumbent. 
inquiry would be necessary to determine whether the employee was prevented from supporting the political party of her choice. If the employee can demonstrate that her employer interfered with her political activities, she has proven a constitutional violation. ${ }^{126}$ Requiring a change in party affiliation is not, however, sufficient in itself to establish a violation.

Although coercion of political affiliation by a public employer may have some secondary effect on the electoral process, in most instances the effect is not significant. Thus the case for judicial action is fairly weak, and in light of the general principle that the judiciary should intervene in the political process only when necessary, requiring public employees to change political affiliation generally should not be considered unconstitutional. The final determination of whether the effect is significant depends, however, on a factual inquiry. The resolution of any particular constitutional challenge will depend on the findings of the trier of facts.

\section{Patronage contracting.}

Interestingly, the structural approach suggests that LaFalce and the other decisions permitting patronage contracting were wrongly decided. By linking public contracts to campaign contributions, ${ }^{127}$ patronage contracting permits incumbents to effect just the sort of political entrenchment of incumbents that a "representation-reinforcing" judiciary should be most anxious to combat. The fact that the infringement of individual rights by patronage contracting is less serious than by patronage employment practices is irrelevant: under a structural approach, the large and pervasive systemic effects are dispositive.

\section{Patronage hiring.}

The structural approach suggests that in most instances patronage hiring does not raise any constitutional problems because the practice has no evident, systemic biasing effects on the political process. While the promise of employment in exchange for political support can provide added incentives for campaigning, it is a

${ }^{128}$ The factual inquiry necessary here is far more empirical and focussed than the factual inquiry courts have undertaken as part of the individual rights approach. The inquiry should focus on demonstrable effects on electoral outcomes and the behavior of individuals, rather than on broad questions of what is the "best" form of government. See section IIIC for a more complete discussion.

${ }^{127}$ See note 121 for evidence of the value of campaign contributions to electoral success. 
promise that, ex ante, all political parties are equally able to make. ${ }^{128}$ Thus, there is no particular bias in favor of the incumbents, or any one else. ${ }^{129}$ If an incumbent offers a supporter a midterm job in exchange for a promise of support in the next election, there is no way for the incumbent to later enforce that promise, since, under the analyis presented above, she cannot fire or discipline the employee for failure to provide support. Thus the challenger is not particularly hampered by the fact that he can only offer jobs as they open up because the incumbent faces the same constraint. Both candidates are similarly situated: they can only make promises to people who have not yet been given patronage positions. ${ }^{130}$

Finally, it should be noted that this discussion of patronage hiring does not resolve the problem of failure to rehire after a layoff. ${ }^{131}$ Rehiring is a power held exclusively by the incumbent party; thus, it is immediately suspect. Furthermore, the incumbent party may avoid other restrictions on patronage practices through a combination of layoffs and rehiring of only those who provide support; this practice too must be prohibited if based on employee's failure to contribute or campaign. Once again, it is the threat of tilting the democratic balance that controls.

In sum, applying a structural view of the First Amendment to patronage cases produces rules of decision that are both clear and categorical. Certain types of actions are absolutely prohibited while others are permitted, and no balancing of interests is required. The greatest advantage of this approach is that decisions are based on

${ }^{128}$ A job promise from a candidate already well ahead in the polls will, it is true, carry appreciably more weight than one from his opponent. But this is due to a preexisting electoral lead, not to some advantage conferred or enhanced by patronage.

${ }^{129}$ It is possible that a long-established majority party could use hiring to maintain its control by preventing new parties from building themselves up. In fact, such a process might be one reason incumbents enjoy high reelection rates, suggesting that patronage hiring by well-established majority parties should be actionable. At least under current law, however, the line of causation has been found too attenuated to state a constitutional claim. See Shakman v Dunne, 829 F2d 1387, 1397 (7th Cir 1987).

${ }_{130}$ The only instance in which patronage hiring raises a real constitutional problem is when an incumbent makes a midterm demand for money in exchange for employment. At this point, the election is too far away for the challenging party to make a parallel offer, and so the party controlling patronage does have a systemic advantage. Only demands for money raise this concern, however, because campaigning will have little impact if the election is far off. Thus, midterm demands for money should be constitutionally prohibited. Such extortion is, of course, already prohibited by the criminal law. The Hobbs Act, 18 USC § 1951. Thus, the issue will arise only when the government (including federal authorities, since this extortion is a federal offense) refuses to prosecute, or cannot prove its case beyond a reasonable doubt.

${ }^{131}$ This was one of the practices at issue in Rutan, $868 \mathrm{~F} 2 \mathrm{~d}$ at 945-46. 
fairly neutral principles, capable of application independent of any political preferences. In most cases, empirical evidence as to the actual effects of any challenged practice will play a crucial role in the decision. Thus, decisions will not rest on vague, value-laden assessments of the relative merits of various moral claims, but on hard, empirical evidence which the parties will have the burden of presenting at trial.

D. Implications for the Patronage Cases: Reassessing the Case Law

In Delong, ${ }^{132}$ a senior federal officer claimed that his transfer from an influential to a relatively powerless position was a politically motivated act by the newly elected Carter Administration, and hence violated the First Amendment. Delong's claim contained no allegation of coercion or a request that he aid the new Administration politically. He was simply transferred so that his old position would be available for a Democrat. Thus, on its face, his was a pure affiliation case, not protected by the First Amendment under a structural approach. It is possible that further fact-finding would reveal some coercion, but the plaintiff failed to prove such coercion in the appellate record.

Rutan involved a much more complicated set of claims, since it was brought by a group of public employees challenging a wide variety of patronage practices, including patronage hiring, rehiring after a layoff, transfers and promotions. ${ }^{133}$ In all cases, the plaintiffs alleged that they were denied benefits because they lacked the support of the Republican Party, and that less qualified but politically preferred people were granted those benefits. The Rutan court affirmed the dismissal of the hiring claims, but remanded all the others. The rules developed above clearly support the outcome in Rutan regarding the hiring claims, since patronage hiring is not prohibited under a structural approach. The correct resolution of the other claims, however, is unclear because the relevant facts are missing from the opinion. Under the structural approach, the crucial inquiry in assessing these claims is why those particular plaintiffs were disfavored, or alternatively, why other employees were preferred. If political affiliation was the sole basis, those plaintiffs have no right to redress. If, however, the preferred employees provided their sponsors with direct political support, by campaigning, 
making financial contributions, or organizing the local party, then the plaintiffs may indeed have a valid claim. These facts would need to be developed on remand. ${ }^{134}$

In contrast to Delong and Rutan, Bennis involved a clear violation of the First Amendment under the structural approach. In Bennis, police officers claimed that they had been demoted in retaliation for supporting the current mayor's opponent in the previous election. ${ }^{135}$ A structural view of the First Amendment clearly prohibits such governmental action, since it allows the incumbent to skew an election in her favor. Prohibiting public employees from campaigning for challengers cannot be distinguished from requiring them to campaign for the incumbents. Thus, the Bennis court did reach the correct result.

Lieberman presented another strong claim for relief under the structural approach. The plaintiff alleged that her employer took various unfavorable actions in retaliation for her political affiliation and her candidacy (as a member of the opposing party) for a position in the local legislature. ${ }^{136}$ Her first allegation, that she was coerced because of her political affiliation, fails to state a claim under the structural approach. But the second allegation, that she was punished for raising an electoral challenge to political affiliates of the incumbent government, just as clearly should state a claim. It is difficult to imagine a more blatant example of an incumbent government using its official powers to protect its position from electoral challenge.

The remaining important cases are much simpler to resolve under the structural approach, and do not merit much discussion. The patronage contracting decisions, Sweeney, Fox \& Co., LaFalce, and Horn, ${ }^{137}$ were wrongly decided. As discussed above, patronage contracting represents a potentially powerful method through which an incumbent government can entrench itself. As such, the judiciary should scrutinize such practices with great care. Finally, patronage hiring cases like Avery $v$ Jennings ${ }^{138}$ were decided correctly under a structural approach. Ex ante patronage hiring has no systematic effect on the electoral process, and so should not be proscribed. Avery was thus correct in its actual holding, but

134 The Rutan court instructed the district court to determine whether the employer's actions were "the substantial equivalent of dismissal." Id at 956. Such an inquiry is obviously irrelevant to the proper resolution of the claims under a structural approach.

$135823 \mathrm{~F} 2 \mathrm{~d}$ at 725 .

138857 F2d at $897-98$.

137 See notes 51-54.

${ }^{138}$ See note 46. 
incorrect in its dictum suggesting that the First Amendment prohibits pure patronage hiring. ${ }^{138}$

Despite the confused nature of the patronage jurisprudence, courts have tended to reach results consistent with the structural approach. Given the considerations on which the decisions were based, however, this consistency has resulted more from fortuity than from any sort of understanding of the structural concerns raised by the cases. The best way to bring order to this area of law is explicitly to adopt a structural approach to patronage cases, rather than purportedly retaining a personal rights approach while in fact concentrating on structural considerations. ${ }^{140}$

\section{CoNCLUSION}

This Comment has shown that the circuit courts of appeal have taken a fundamentally incorrect approach in considering how far to extend the Supreme Court's holding in Elrod v Burns to patronage practices short of dismissal. Instead of trying to balance the interests of the individual employees against those of the government, the judiciary should consider its role to be one of "representation-reinforcement" and should evaluate patronage practices on the basis of whether they threaten to subvert the democratic political process. This approach will yield clearer rules of decision, and will minimize judicial involvement in value-laden political disputes.

The "representation-reinforcement" view of the judiciary's role stems from an interpretation of the Constitution generally, and the First Amendment in particular, which emphasizes the

$138786 \mathrm{~F} 2 \mathrm{~d}$ at 234.

140 The structural view suggests that only voters are injured by governmental actions violating the First Amendment. Thus, presumably, voters should have standing to bring suit challenging such actions. However, the current standing doctrine requires that a plaintiff suffer "personal injury fairly traceable to the defendant's allegedly unlawful conduct." Allen $v$ Wright, 468 US 737, 751 (1984). In order to accommodate structural injuries in the patronage context, courts should either interpret the phrase "personal injury" fairly broadly, or they should reform the standing doctrine to take into account a structural view of the First Amendment. See Erwin Chemerinsky, Protecting the Democratic Process: Voter Standing to Challenge Abuses of Incumbency, 49 Ohio St L J 773 (1988).

The actual status of standing doctrine in the patronage area is far from clear. See Shakman, 829 F2d at 1397 (holding that voters and independent candidates do not have standing to challenge a patronage hiring system). By refusing to decide whether "plaintiffs would have standing to attack the constitutionality of the coerced political work demanded of those already employed by the government as a condition of continued employment," the Shakman decision may suggest that standing exists in situations in which a structural approach would find a constitutional violation because of coercion of current employees. Id at 1398. Compare Winpisinger v Watson, 628 F2d 133, 141 \& n 32 (DC Cir 1980). 
structural concerns central to those texts. This approach emphasizes that the Framers never intended the Constitution to embody a particular set of values; instead, they sought to provide a framework in which the citizen body would be allowed to discover and enforce its own political views. The central purpose of the Constitution was thus to insure that the political process itself remained free and untainted. The First Amendment plays a crucial role in that scheme, as a means to prevent the current incumbents, the "insiders", from using the power of the state to entrench themselves and tilt the political balance in their favor. The patronage cases represent just one context-albeit a very important one-in which the judiciary can use the First Amendment to protect the political process from subversion. 
